\title{
PENGARUH DIVIDEN, HUTANG, INVESTASI, DAN \\ PROFITABILITAS TERHADAP NILAI PERUSAHAAN \\ (Studi Kasus Sektor Aneka Industri di Bursa Efek Indonesia \\ 2012-2014)
}

\author{
Lia Indrayanti \\ Liaindrayanti93@gmail.com \\ Universitas Ahmad Dahlan
}

Rikha Muftia Khoirunnisa

Move.tya@gmail.com

Universitas Ahmad Dahlan

\begin{abstract}
ABSTRAK
This study aims to examine the effect of dividends, debt, investment, and profitability to firm value (case studies of various sectors industry on the Indonesia Stock Exchange 20122014). The sample in this study is companies in various industrial sectors. Deep sampling technique. This research uses purposive sampling technique, obtained 7 samples companies in various industrial sectors. Test by using a test statistical analysis of multiple linear regression. Partially, statistical tests are used is the t test and simultaneously with the F test. Based on the results the research can be concluded that partially dividends have no effect to the value of the company in various industrial sectors, debt, investment, and profitability affects the value of the company in various industrial sectors, and simultaneously dividends, debt, investment, and profitability have an effect to the value of the company in various industrial sectors.
\end{abstract}

Keyword: Dividen Payout Ratio; Debt to Equity Rate; Price Earning Ratio; Return on Equity; Price to Book Value.

\footnotetext{
PENDAHULUAN

\begin{tabular}{l}
\hline \multicolumn{3}{c}{ PENDAHULUAN } \\
Nilai perusahaan merupakan \\
persepsi investor terhadap tingkat \\
keberhasilan perusahaan yang sering \\
dikaitkan dengan harga saham. Harga \\
saham yang tinggi membuat nilai \\
perusahaan juga tinggi. Memaksimalkan \\
nilai perusahaan sangat penting artinya \\
bagi suatu perusahaan, karena dengan \\
memaksimalkan nilai perusahaan berarti \\
juga memaksimalkan kemakmuran \\
pemegang saham yang merupakan tujuan \\
utama perusahaan. \\
Dividen merupakan bagian yang \\
tidak dapat dipisahkan dengan \\
keputusan pendanaan perusahaan. Nilai \\
perusahaan ditentukan oleh nilai modal \\
sendiri dan nilai hutang. Sementara itu jika
\end{tabular}
}

diperhatikan model harga saham untuk satu perusahaan yang mengalami pertumbuhan konstan menunjukkan bahwa pembayaran dividen yang lebih besar cenderung akan meningkatkan nilai saham. Kemudian meningkatnya harga saham berarti meningkatnya nilai perusahaan. Namun pembayaran dividen yang semakin besar juga akan mengurangi kemampuan perusahaan untuk investasi, sehingga akan menurunkan tingkat pertumbuhan perusahaan dan akan menurunkan nilai saham. Dividen adalah keputusan apakah laba yang diperoleh perusahaan akan dibagikan kepada pemegang saham dalam bentuk dividen atau akan ditahan untuk menambah modal dalam bentuk laba ditahan guna pembiayaan investasi dimasa yang akan datang. Apabila 
perusahaan memilih untuk membagikan laba sebagai dividen, maka akan mengurangi laba yang ditahan dan mengurangi total sumber dana intern atau keuangan internal. Sebaliknya jika perusahaan memilih untuk menahan laba yang diperoleh, maka kemampuan pembentukan dana intern akan semakin besar.

Hutang dalam sebuah perusahaan haruslah bertujuan untuk memaksimalkan kemakmuran. Dalam hal ini kebijakan tersebut harus mempertimbangkan dan menganalisis kombinasi sumber-sumber dana yang ekonomis bagi perusahaan guna membiayai kebutuhan-kebutuhan rutin serta investasi bagi perusahaan. Selain mendapatkan sumber dana dari modal sendiri yaitu menerbitkan saham preferen, saham biasa, atau juga dari laba ditahan, perusahaan juga dapat mendapatkan sumber dana dari kreditur berupa hutang jangka panjang. Hutang jangka panjang sendiri dapat diartikan sebagai kewajiban perusahaan yang mempunyai waktu lebih dari satu tahun atau satu siklus operasi perusahaan. Pada umumnya hutang jangka panjang digunakan untuk ekspansi perusahaan, mempunyai jumlah yang besar dan waktu yang lama. Demikian halnya dengan kebijakan hutang sebuah perusahaan dimana keputusan tentang penggunaan hutang digunakan untuk memaksimalkan kemakmuran pemilik perusahaan selain untuk memaksimalkan profit. Hutang merupakan keputusan yang sangat penting dalam perusahaan karena kebijakan hutang merupakan salah satu bagian dari kebijakan pendanaan perusahaan.

Hutang adalah kebijakan yang diambil oleh pihak manajemen dalam rangka memperoleh sumber pembiayaan bagi perusahaan sehingga dapat digunakan untuk membiayai aktivitas operasional perusahaan. Sumber pendanaan dapat diperoleh dari modal internal dan modal eksternal. Modal internal berasal dari laba ditahan, sedangkan modal eksternal adalah dana yang berasal dari para kreditur dan pemilik, peserta atau pengambil bagian didalam perusahaan.

Investasi adalah penanaman modal dengan harapan akan memperoleh keuntungan dimasa yang akan datang (Jogiyanto, 2010). Investasi modal merupakan salah satu aspek utama dalam keputusan investasi selain penentuan komposisi aktiva. Keputusan pengalokasian modal ke dalam usulan investasi harus dievaluasi dan dihubungkan dengan risiko dan hasil yang diharapkan (Wijaya dan Wibawa, 2010). Menurut signaling theory, pengeluaran investasi memberikan sinyal positif mengenai pertumbuhan perusahaan dimasa yang akan datang, sehingga dapat meningkatkan harga saham yang digunakan sebagai indikator nilai perusahaan (Wahyudi dan Pawestri, 2006). Investasi merupakan keputusan yang dikeluarkan perusahaan terkait dengan kegiatan perusahaan untuk melepaskan dana pada saat sekarang dengan harapan untuk menghasilkan arus dana masa mendatang dengan jumlah yang lebih besar dari yang dilepaskan pada saat investasi awal, sehingga harapan perusahaan untuk selalu tumbuh berkembang akan semakin jelas dan terencana (Sartono, 2001), keputusan investasi menyangkut tentang keputusan alokasi dana, baik dana yang berasal dari dalam perusahaan maupun dana yang berasal dari luar perusahaan pada berbagai bentuk investasi.

Profit dalam kegiatan operasional perusahaan merupakan elemen penting untuk menjamin kelangsungan hidup perusahaan pada masa yang akan datang. Keberhasilan perusahaan dapat dilihat dari kemampuan perusahaan menciptakan laba yang berasal dari pembiayaan yang dilakukan, kemampuan perusahaan untuk dapat bersaing dipasar (survive), dan kemampuan perusahaan untuk dapat melakukan ekpansi usaha (developt). Profitabilitas merupakan kemampuan suatu perusahaan dalam mencari keuntungan dari penggunaan modalnya. 
Profitabilitas merupakan kemampuan perusahaan untuk memperoleh laba dari modal yang digunakan untuk menghasilkan laba dan kemampuan perusahaan untuk menciptakan laba dengan menggunakan modal yang cukup tersedia. Kinerja manajerial dari setiap perusahaan akan dapat dikatakan baik apabila tingkat profitabilitas perusahaan yang dikelolanya tinggi ataupun dengan kata lain maksimal, dimana profitabilitas ini umumnya selalu diukur dengan membandingkan laba yang diperoleh perusahaan dengan sejumlah perkiraan yang menjadi tolak ukur keberhasilan perusahaan. Adanya kemampuan memperoleh laba dengan menggunakan semua sumber daya perusahaan maka tujuan-tujuan perusahaan akan dapat tercapai. Penggunaan semua sumber daya tersebut akan memungkinkan perusahaan untuk memperoleh laba yang tinggi.

Profitabilitas juga mempunyai arti penting dalam usaha mempertahankan kelangsungan hidupnya dalam jangka panjang, karena profitabilitas menunjukkan apakah badan usaha tersebut mempunyai prospek yang baik dimasa yang akan datang. Dengan demikian setiap badan usaha akan selalu berusaha meningkatkan profitabilitasnya, karena semakin tinggi tingkat profitabilitas suatu badan usaha maka kelangsungan hidup badan usaha tersebut akan lebih terjamin. Profitabilitas suatu perusahaan menunjukkan perbandingan antara laba dengan aktiva atau modal yang menghasilkan laba tersebut. Dengan kata lain, profitabilitas adalah kemampuan suatu perusahaan untuk mencapai laba.

\section{Rumusan Masalah}

1. Apakah dividen berpengaruh terhadap nilai perusahaan sektor aneka industri di Bursa Efek Indonesia 2012-2014?

2. Apakah hutang berpengaruh terhadap nilai perusahaan sektor aneka industri di Bursa Efek Indonesia 2012-2014?

3. Apakah investasi berpengaruh terhadap nilai perusahaan sektor aneka industri di Bursa Efek Indonesia 20122014 ?

4. Apakah profitabilitas berpengaruh terhadap nilai perusahaan sektor aneka industri di Bursa Efek Indonesia 2012 2014?

5. Apakah dividen, hutang, investasi, dan profitabilitas secara simultan berpengaruh terhadap nilai perusahaan sektor aneka industri di Bursa Efek Indonesia 2012-2014?

\section{REVIEW LITERATUR DAN HIPOTESIS}

\section{Landasan Teori \\ Nilai perusahaan}

Nilai perusahaan adalah sangat penting karena dengan nilai perusahaan yang tinggi akan diikuti oleh tingginya kemakmuran pemegang saham (Brigham dan Houston, 2004). Semakin tinggi harga saham semakin tinggi nilai perusahaan. Nilai perusahaan yang tinggi menjadi keinginan para pemilik perusahaan, sebab dengan nilai yang tinggi menunjukkan kemakmuran pemegang saham juga tinggi. Kekayaan pemegang saham dan perusahaan dipresentasikan oleh harga pasar dan saham yang merupakan cerminan dari keputusan investasi, pendanaan (financing), dan manajemen asset.

$$
\mathrm{PBV}=\frac{\text { Harga per Lembar Saham }}{\text { Nilai Buku per Lembar Saham }} \times 100 \%
$$

\section{Dividen}

Dividen merupakan sebagai keputusan tentang apakah laba yang diperoleh perusahaan akan dibagikan 
kepada pemegang saham sebagai dividen atau akan ditahan dalam bentuk laba ditahan guna pembiayaan investasi di masa yang akan datang. Apabila perusahaan memilih untuk membagikan laba sebagai dividen, maka akan mengurangi laba yang ditahan dan selanjutnya mengurangi total sumber dana intern atau internal financing. Sebaliknya jika perusahaan memilih untuk menahan laba yang diperoleh, maka kemampuan pembentukan dana intern akan semakin besar (Sartono, 2001).

\section{Dividen per Lembar Saham}

DPR $=\longrightarrow \times 100 \%$

Laba per Lembar Saham

\section{Hutang}

Hutang merupakan suatu mekanisme yang bisa digunakan untuk mengurangi atau mengontrol konflik keagenan. Dengan adanya hutang perusahaan harus melakukan pembayaran periodik atas bunga dan principal. Penggunaan hutang perusahaan akan memaksa manajemen untuk bertindak lebih efisien dan tidak konsumtif karena adanya risiko kebangkrutan, penggunaan hutang dapat untuk mengurangi agency conflict dan asimetri informasi perusahaan mengeluarkan hutang berarti memberikan signal kepada investor akan kemampuan kondisi keuangan perusahaan di masa depan.

\section{Total Hutang$$
\text { DER }=\longrightarrow \times 100 \%
$$ \\ Total Modal}

\section{Investasi}

Investasi adalah komitmen atas sejumlah dana atau sumber daya lain yang dilakukan saat ini dengan tujuan memperoleh keuntungan dimasa datang. Optimalisasi nilai perusahaan yang merupakan tujuan perusahaan dapat dicapai melalui pelaksanaan fungsi manajemen keuangan, dimana satu keputusan keuangan yang diambil akan mempengaruhi keputusan keuangan lainnya dan berdampak pada nilai perusahaan (Fama dan French, 1998). Kebijakan investasi sering juga disebut capital budgeting problem, adalah masalah bagaimana manajer harus mengalokasikan dana kedalam bentuk bentuk investasi yang akan dapat mendatangkan keuntungan dimasa depan (Basri, 2002).

$$
\text { PER }=\frac{\text { Harga per Lembar Saham }}{\text { Laba per Lembar Saham }} \times 100 \%
$$

\section{Profitabilitas}

Profitabilitas menurut Sartono (1997) adalah kemampuan perusahaan memperoleh laba dalam hubungan dengan penjualan, total aktiva maupun modal sendiri. Rasio profitabilitas ini akan memberikan gambaran tentang tingkat efektifitas pengelolaan perusahaan. Semakin tinggi profitabilitas berarti semakin baik, karena kemakmuran pemilik perusahaan meningkat dengan semakin tingginya profitabilitas. Profitabilitas perusahaan adalah tingkat keuntungan bersih yang mampu diraih oleh perusahaan pada saat menjalankan operasinya (Nurhayati, 2013).

\section{Laba Bersih Setelah Pajak

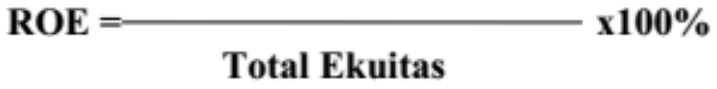

\section{Penelitian Terdahulu}

1. Hasil penelitian Hasnawati (2005) menunjukkan bahwa, investasi berpengaruh positif dan signifikan terhadap nilai perusahaan. Investasi ini lebih kuat dibentuk oleh indikator indikator peluang investasi di masa yang akan datang dibandingkan dengan komposisi asset dalam perusahaan.

2. Hasil penelitian Wijaya dan Wibawa (2010) menunjukkan bahwa, investasi, hutang dan dividen secara parsial dan simultan berpengaruh positif dan signifikan terhadap nilai perusahaan 
3. Hasil penelitian Rakhimsyah dan Gunawan (2011) menunjukkan bahwa, investasi berpengaruh positif dan signifikan terhadap nilai perusahaan, keputusan pendanaan tidak berpengaruh terhadap nilai perusahaan dan dividen berpengaruh negatif dan signifikan terhadap nilai perusahaan.

4. Hasil penelitian Ahmad dan Putri (2012) menunjukkan bahwa, dividen secara parsial memiliki pengaruh yang tidak signifikan terhadap nilai perusahaan, hutang bepengaruh positif tetapi tidak signifikan terhadap nilai perusahaan, profitabilitas berpengaruh positif dan signifikan terhadap nilai perusahaan.

5. Hasil penelitian Nurhayati (2013) menunjukkan bahwa, profitabilitas berpengaruh positif dan signifikan terhadap nilai perusahaan sedangkan dividen tidak berpengaruh signifikan terhadap nilai perusahaan.

\section{Hipotesis}

H1: Dividen berpengaruh terhadap nilai perusahaan

H2: Hutang berpengaruh terhadap nilai perusahaan

H3: Investasi berpengaruh terhadap nilai perusahaan

H4: Profitabilitas berpengaruh terhadap nilai perusahaan.

H5: Dividen, hutang, investasi, dan profitabilitas secara simultan berpengaruh terhadap nilai perusahaan

\section{METODE PENELITIAN}

\section{Populasi dan Sampel}

Populasi adalah wilayah generalisasi yang terdiri dari obyek atau subyek yang mempunyai kualitas dan karakteristik tertentu yang ditetapkan oleh peneliti untuk dipelajari dan kemudian ditarik kesimpulannya (Sugiyono, 2009). Populasi penelitian ini adalah perusahaan sektor aneka industri di Bursa Efek Indonesia 2012-2014.

Sampel merupakan bagian dari populasi yang digunakan sebagai objek penelitian. Dalam penelitian ini, sampel ditentukan dengan menggunakan metode purposive sampling. Metode sampling tersebut membatasi pemilihan sampel berdasarkan kriteria tertentu

\section{Definisi Operasional}

1. Variabel Independen

\section{Dividen ( $\left.\mathbf{X}_{1}\right)$}

Dividen adalah keputusan tentang seberapa banyak laba saat ini yang akan dibayarkan sebagai dividen daripada ditahan untuk diinvestasikan kembali dalam perusahaan (Brigham dan Houston, 2011). Dalam penelitian ini dividen diproksikan dengan Dividend Payout Ratio (DPR), karena DPR dapat menggambarkan perilaku oportunistik manajerial yaitu dengan melihat berapa besar keuntungan yang dibagikan kepada shareholders sebagai dividen dan berapa yang disimpan di perusahaan. Rumus dividend payout ratio adalah sebagai berikut:

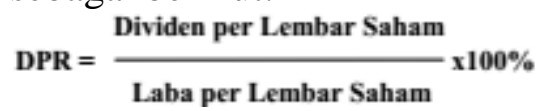

\section{Hutang ( $\left.\mathbf{X}_{2}\right)$}

Hutang merupakan kewajiban perusahaan kepada pihak lain untuk membayar sejumlah uang atau menyerahkan barang atau jasa pada tanggal tertentu. Hutang juga merupakan salah satu sumber pembiayaan eksternal yang digunakan oleh perusahaan untuk membiayai kebutuhan dananya. Dalam pengambilan keputusan akan penggunaan hutang ini, harus mempertimbangkan besarnya biaya tetap yang muncul dari hutang berupa bunga yang akan menyebabkan semakin meningkatnya leverage keuangan dan semakin tidak pastinya 
tingkat pengembalian bagi para pemegang saham biasa.

DER $=\frac{\text { Total Hutang }}{\text { Total Modal }} \times 100 \%$

\section{Investasi $\left(\mathrm{X}_{3}\right)$}

Investasi adalah keputusan yang menyangkut harapan terhadap hasil keuntungan yang diperoleh perusahaan di masa yang akan datang. Investasi merupakan komitmen atas sejumlah dana atau sumber daya lain yang dilakukan saat ini dengan tujuan memperoleh keuntungan di masa datang.

PER $=\frac{\text { Harga per Lembar Saham }}{\text { Laba per Lembar Saham }} \times 100 \%$

\section{Profitabilitas $\left(\mathbf{X}_{4}\right)$}

Dalam penelitian ini profitabilitas diproksikan dengan Return on Equity (ROE), karena ROE digunakan untuk mengukur laba bersih setelah pajak dengan modal sendiri. Rasio ini menunjukkan daya untuk menghasilkan laba atas investasi berdasarkan nilai buku para pemegang saham. Semakin tinggi rasio ini, semakin baik, artinya posisi pemilik perusahaan semakin kuat, demikian pula sebaliknya. ROE yang tinggi akan dapat mendorong penerimaan perusahaan atas peluang investasi yang baik dan manajemen biaya yang efektif. Hal ini akan mempengaruhi minat para investor untuk melakukan transaksi jual beli saham, sehingga akan meningkatkan volume penjualan saham perusahaan tersebut. Dengan kata lain tingkat ROE akan memberikan pengaruh terhadap volume penjualan saham perusahaan. Rumus return on equity adalah sebagai berikut:

$\mathrm{ROE}=\frac{\text { Laba Bersih Setelah Pajak }}{\text { Total Ekuitas }} \times 100 \%$

2. Variabel Dependen

Dalam penelitian ini nilai perusahaan di proksikan dengan Price to Book Value (PBV), karena PBV dapat mengukur nilai yang diberikan pasar kepada manajemen dan organisasi perusahaan sebagai sebuah perusahaan yang terus tumbuh (Brigham dan Houston, 2011). Rumus price to book value dapat dihitung sebagai berikut:

$$
\text { PBV }=\frac{\text { Harga per Lembar Saham }}{\text { Nilai Buku per Lembar Saham }} \times 100 \%
$$

\section{Teknik Analisis Data}

1. Uji Asumsi Klasik

\section{Uji Normalitas}

Uji normalitas ini bertujuan untuk menguji apakah dalam model regresi, variabel independen dan variabel dependen keduanya memiliki distribusi normal atau tidak (Ghozali, 2009). Uji normalitas menggunakan uji Kolmogorov-Smirnov (uji K-S) dengan bantuan program komputer SPSS.

\section{Autokorelasi}

Uji autokorelasi dimaksudkan untuk mengetahui apakah terjadi korelasi antara anggota serangkaian data observasi yang diuraikan menurut waktu (time series) atau ruang (cross section). Hal ini mempunyai arti bahwa suatu tahun tertentu dipengaruhi oleh tahun berikutnya, untuk menguji ada tidaknya autokorelasi ini dapat dilakukan dengan menggunakan watson statistik, yaitu dengan melihat koefisien korelasi Durbin-Watson.

\section{Uji Multikolinieritas}

Multikolinieritas merupakan situasi dimana terdapat hubungan yang kuat antara variabel-variabel independen menurut (Ghozali, 2006). Uji multikolinieritas bertujuan untuk menguji apakah dalam model regresi ditemukan adanya korelasi antar variabel bebas (independen). Dalam model regresi tidak boleh terjadi korelasi diantara variabel independen. Jika variabel independen saling 
berkorelasi maka variabelvariabel tidak orthogonal. Variabel orthogonal adalah variabel independen yang nilai korelasi antar sesama variabel independen sama dengan nol.

\section{Uji Heteroskedastisitas}

Uji heteroskedastisitas bertujuan untuk menguji apakah dalam model regresi terjadi ketidaksamaan varians dari residu suatu pengalaman kepengalaman lain. Jika dari suatu pengalaman tersebut terdapat varians yang berbeda,

\section{Analisis Regresi Berganda}

Alat analisis statistik yang digunakan adalah model regresi linear berganda. Model analisis ini dipilih karena penelitian ini dirancang untuk meneliti faktor-faktor yang berpengaruh pada variabel independen terhadap variabel dependen, dimana variabel independen yang digunakan dalam penelitian ini lebih dari satu. Model persamaan regresi linear berganda sebagai berikut

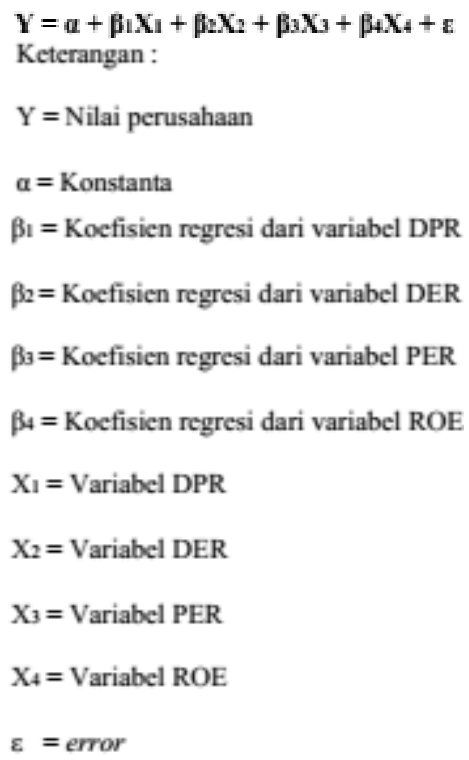

\section{Uji Hipotesis}

\section{Uji Parsial (Uji T)}

Pengujian koefisien regresi parsial (uji t) merupakan pengujian masingmasing variabel independen yang dilakukan untuk melihat apakah masing-masing variabel independen berpengaruh secara signifikan terhadap variabel independen, uji $t$ dalam penelitian ini menggunakan tingkat signifikansi 5\%. Uji statistik t pada dasarnya menunjukkan seberapa jauh pengaruh suatu variabel penjelas atau independen secara parsial dalam menerangkan variasi variabel dependen (Ghozali, 2006). Kriteria uji t yang digunakan, jika nilai signifikansi < alpha sebesar $5 \%$ atau 0,05 maka $\mathrm{H}_{0}$ ditolak dan Ha diterima, yaitu variabel independen atau eksplenatory secara signifikan mempengaruhi variabel dependen.

\section{Uji Simultan (Uji F)}

Uji $F$ hitung dimaksudkan untuk menguji model regresi atas pengaruh seluruh variabel independen secara simultan terhadap variabel dependen. Uji $F$ dapat dilakukan dengan melihat tingkat signifikansi F pada output hasil regresi dengan level significant 5\%. Jika nilai signifikansi lebih besar dari 5\% maka $\mathrm{H}_{0}$ diterima dan $\mathrm{Ha}$ ditolak (koefisien regresi tidak signifikan), artinya secara simultan variabel-variabel independen tidak mempunyai pengaruh signifikan terhadap variabel dependen. Jika nilai signifikansi lebih kecil dari 5\% maka $\mathrm{Ha}$ diterima dan $\mathrm{H}_{0}$ ditolak (koefisien regresi signifikan), artinya secara simultan variabel-variabel independen mempunyai pengaruh signifikan terhadap variabel dependen.

\section{Uji Koefisien Determinasi}

Koefisien determinasi adalah nilai yang menunjukkan seberapa besar variabel independen dapat menjelaskan variabel dependennya. Koefisien determinasi mengukur seberapa jauh kemampuan model dalam menerangkan variasi variabel dependen (Ghozali, 2009). Nilai adjusted $\mathrm{R}_{2}$ merupakan suatu ukuran ikhtisar yang menunjukkan seberapa garis regresi 
sampel cocok dengan data populasinya. Nilai koefisien determinasi adalah antara 0 dan 1 . Uji koefisien determinasi dilihat dari nilai R Square, bila nilai $\mathrm{R}$ Square $=0$ berarti pengaruh variabel independen terhadap variabel dependen lemah sedangkan bila nilai $\mathrm{R}$ Square $=1$ berarti pengaruh variabel independen terhadap variabel dependen kuat.

\section{HASIL PENELITIAN DAN PEMBAHASAN}

\section{Statistik Deskriptif}

Tabel 4.3

\begin{tabular}{|c|c|c|c|}
\hline & \multicolumn{2}{|c|}{ Mean } & \multirow{2}{*}{$\frac{\text { Std. Deviation }}{\text { Statistic }}$} \\
\hline & Statistic & Std. Error & \\
\hline DPR & 3692,30598 & 1967,245532 & 9015,051560 \\
\hline DER & ,96952 & ,087275 & ,399943 \\
\hline PER & 16,27000 & 2,102321 & 9,634046 \\
\hline ROE & 17,83810 & 2,258850 & 10,351351 \\
\hline PBV & 2,33143 &, 318325 & 1,458747 \\
\hline $\begin{array}{l}\text { Valid N } \\
\text { (listwise) }\end{array}$ & & & \\
\hline (listwise) & & & \\
\hline
\end{tabular}

\section{Hasil Penelitian}

1. Uji Asmusi Klasik

Tabel 4.4

Hasil Uji Normalitas

One-Sample Kolmogorov-Smirnov Test

\begin{tabular}{|ll|r|}
\hline & & $\begin{array}{r}\text { Unstandardi } \\
\text { zed Residual }\end{array}$ \\
\hline $\mathrm{N}$ & & 21 \\
Normal Parameters & a,b & Mean \\
& Std. Deviation & $0 \mathrm{E}-7$ \\
Most Extreme & Absolute &, 52594504 \\
Differences & Positive &, 094 \\
Kolmogorov-Smirnov Z & Negative &,- 092 \\
Asymp. Sig. (2-tailed) &, 431 \\
\hline
\end{tabular}

a. Test distribution is Normal.

b. Calculated from data.

Sumber : Data Sekunder, diolah 2016

Suatu data dikatakan terdistribusi normal jika nilai probabilitas (p) uji One-Sample Kolmogorov Smirnoz-Z > 0,05 . Berdasarkan output diatas dapat diketahui bahwa nilai probabilitas sebesar 0,992 karena nilai probabilitas $>0,05$ maka dapat disimpulkan bahwa data dalam penelitian ini berdistribusi normal.
2. Uji Autokorelasi

Tabel 4.5

Hasil Uji Autokorelasi

\begin{tabular}{|r|}
\hline \multicolumn{2}{|c|}{ Durbin Watson } \\
\hline 2,240 \\
\hline
\end{tabular}

a. Predictor: (Constant), ROE, PER, DER, DPR

b. Dependent Variable: PBV

Sumber: Data Sekunder, diolah 2016

Berdasarkan output di atas, diketahui nilai Durbin-Watson sebesar 2,240. Selanjutnya nilai ini akan dibandingkan dengan nilai tabel signifikansi $5 \%$, jumlah sampel $\mathrm{N}=21$ dan jumlah variabel independen 4 $(\mathrm{K}=4)=4 \cdot 21=84$. Maka diperoleh nilai dU sebesar 1,8116. Nilai DurbinWatson sebesar 2,240 lebih besar dari batas atas (dU) yakni 1,8116 dan kurang dari (4-dU) 4-1,8116= 2,1884 sehingga dapat disimpulkan bahwa tidak terjadi autokorelasi.

3. Uji Multikolineritas

Tabel 4.6

Hasil Uji Mulitikolinearitas

\begin{tabular}{|l|r|l|}
\hline Variabel & Tolerance & VIF \\
\hline DPR &, 819 & 1,221 \\
\hline DER &, 784 & 1,275 \\
\hline PER &, 733 & 1,365 \\
\hline ROE &, 600 & 1,667 \\
\hline
\end{tabular}

Sumber: Data Sekunder, diolah 2016

Dari hasil perhitungan diatas dengan dibantu SPSS 20 menunjukkan bahwa masing-masing variabel mempunyai nilai tolerance di atas 0,1 dan nilai VIF kurang dari 10. Dengan demikian, data yang diolah menunjukkan antar variabel independen tidak terjadi adanya gejala multikolinearitas. 
4. Uji Heteroskedastisitas

Gambar 4.1

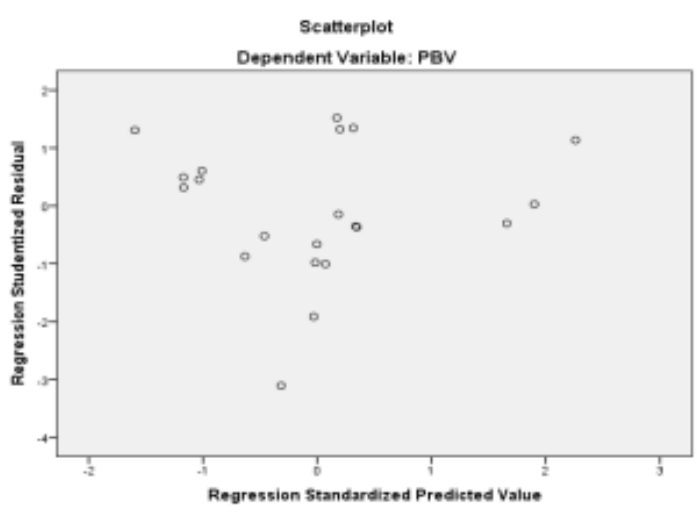

Sumber: Data Sekunder, diolah 2016

Berdasarkan diagram pencar diatas, maka dapat dilihat bahwa sebaran titik-titik acak (random) tidak membentuk suatu pola atau trend garis tertentu, maka disimpulkan tidak terjadi heteroskedastisitas pada model regresi.

5. Hasil Uji Regresi Linier Berganda

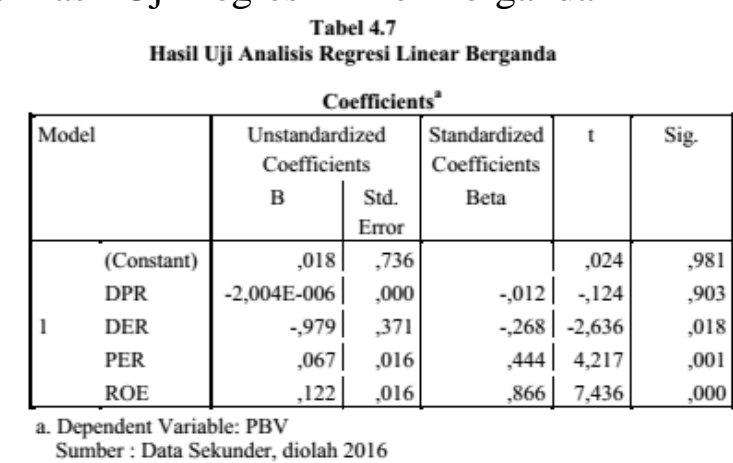

$$
\begin{aligned}
& \mathrm{Y}=0,018-2,004 \mathrm{E}-006 \mathrm{X}_{1}-0,979 \mathrm{X}_{2}+0,067 \mathrm{X}_{3}+0,122 \mathrm{X}_{4}+\varepsilon \\
& \text { Adapun penjelasan dari model } \\
& \text { regresi di atas dapat dijabarkan sebagai }
\end{aligned}
$$

nilai perusahaan akan turun sebesar 2,004E-006.

c. Nilai koefisien regresi hutang $\left(\beta_{2}\right)$ sebesar 0,979 menujukkan bahwa saat hutang naik sebesar satu satuan maka nilai perusahaan akan naik sebesar 0,979. Sebaliknya saat hutang turun satu satuan maka nilai perusahaan akan turun sebesar 0,979 . d. Nilai koefisien regresi investasi $(\beta 3)$ sebesar 0,067 menujukkan bahwa saat investasi naik sebesar satu satuan maka nilai perusahaan akan naik sebesar 0,067. Sebaliknya saat investasi turun satu satuan maka nilai perusahaan akan turun sebesar 0,067. e. Nilai koefisien regresi profitabilitas $(\beta 4)$ sebesar 0,122 menujukkan bahwa saat profitabilitas naik sebesar satu satuan maka nilai perusahaan akan naik sebesar 0,122. Sebaliknya saat profitabilitas turun satu satuan maka nilai perusahaan akan turun sebesar 0,122 .

\section{Hasil Uji Parsial (Uji T)}

Membandingkan taraf signifikansi dan pengambilan keputusan:

1. Untuk variabel dividen, karena nilai signifikan > alpha yaitu 0,903> 0,05 maka $\mathrm{H}_{0}$ diterima, berarti variabel dividen secara parsial tidak berpengaruh terhadap variabel nilai perusahaan sektor aneka industri pada tahun 2012-2014, berarti $\mathrm{H}_{1}$ tidak terdukung.

2. Untuk variabel hutang, karena nilai signifikan < alpha yaitu 0,018 < 0,05 maka $\mathrm{Ha}$ diterima, berarti variabel hutang secara parsial berpengaruh terhadap variabel nilai perusahaan sektor aneka industri pada tahun 2012-2014, berarti $\mathrm{H}_{2}$ terdukung.

3. Untuk variabel investasi, karena nilai signifikan < alpha yaitu $0,001<$ 0,05 maka $\mathrm{Ha}$ diterima, berarti variabel investasi secara parsial 
berpengaruh terhadap variabel nilai perusahaan sektor aneka industri pada tahun 2012-2014, berarti $\mathrm{H}_{3}$ terdukung.

4. Untuk variabel profitabilitas, karena nilai signifikan < alpha yaitu 0,000 $<0,05$ maka $\mathrm{Ha}$ diterima, berarti variabel profitabilitas secara parsial berpengaruh terhadap variabel nilai perusahaan sektor aneka industri pada tahun 2012-2014, berarti $\mathrm{H}_{4}$ terdukung.

7. Hasil Uji Simultan (Uji F)

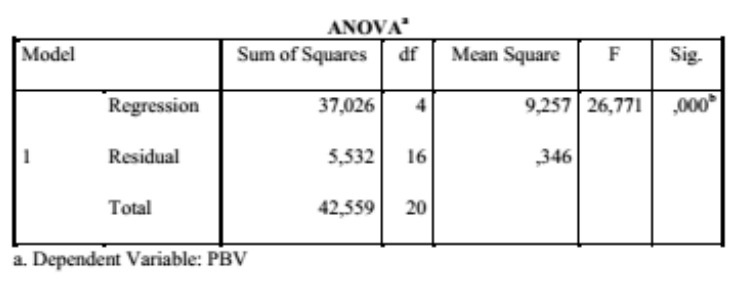

b. Predictors: (Constant), ROE, PER, DER, DPR

Sumber: Data Sekunder, diolah 2016

8. Hasil Uji Koefisien Determinasi

Tabel 4.9

Hasil R Square

\begin{tabular}{|l|r|r|r|c|}
\hline Model & \multicolumn{1}{|c|}{ R } & R Square & Adjusted R Square & $\begin{array}{c}\text { Std. Error of the } \\
\text { Estimate }\end{array}$ \\
\hline 1 &, $933^{3}$ &, 870 &, 838 & \multicolumn{1}{c|}{, 588024} \\
\hline
\end{tabular}

a. Predictors: (Constant), ROE, PER, DER, DPR

b. Dependent Variable: PBV

Sumber : Data Sekunder, diolah 2016

\section{Pembahasan}

Berdasarkan hasil pengolahan data mengenai dividen, hutang, investasi, profitabilitas, dan nilai perusahaan maka dapat diketahui bahwa : Dividen dengan menggunakan uji $\mathrm{t}$ tidak berpengaruh terhadap nilai perusahaan. Dimana tinggi rendahnya dividen yang dibayarkan kepada pemegang saham, tidak berkaitan perusahaan. Kebijakan dividen merupakan hak pemegang saham untuk. mendapatkan sebagian dari keuntungan perusahaan, pembayaran dividen juga akan dapat mengurangi peluang investasi karena investor lebih menyukai capital gain daripada dividen karena pajak capital gain lebih kecil daripada pajak dividen. Kebijakan dividen tidak mampu meningkatkan nilai perusahaan pada saat hutang rendah dan kebijakan dividen tidak dapat menurunkan nilai perusahaan pada saat hutang tinggi dan rasio pembayaran dividen hanyalah rincian yang tidak mempengaruhi kesejahteraan pemegang saham. Meningkatnya nilai dividen tidak selalu diikuti dengan meningkatnya nilai perusahaan. Karena nilai perusahaan ditentukan hanya oleh kemampuan perusahaan menghasilkan laba dari aset aset perusahaan atau kebijakan investasinya. Hasil ini konsisten dengan penelitian yang dilakukan Nurhayati (2013) yang menyatakan bahwa secara parsial kebijakan dividen tidak mempunyai pengaruh terhadap nilai perusahaan.

Hutang dengan menggunakan uji $\mathrm{t}$ mempunyai pengaruh terhadap nilai perusahaan, artinya pendanaan yang melalui hutang akan meningkatkan nilai perusahaan dimana perusahaan yang memiliki hutang akan membayar bunga pinjaman yang dapat mengurangi penghasilan kena pajak yang dapat memberikan manfaat bagi pemegang saham dan penggunaan hutang dapat mempengaruhi harga saham perusahaan. Semakin besar hutang, maka akan semakin meningkatkan nilai perusahaan. Perusahaan dengan tingkat hutang yang tinggi akan dapat meningkatkan laba perlembar sahamnya yang akhirnya akan meningkatkan harga saham. perusahaan yang berarti akan meningkatkan nilai perusahaan. Peningkatan hutang dapat diartikan pihak luar mengenai kemampuan perusahaan untuk membayar kewajibannya dimasa yang akan datang atau resiko bisnis yang rendah, sehingga penambahan hutang telah memberikan sinyal positif karena manajemen mengambil proyek-proyek yang resikonya lebih besar daripada yang diperkirakan oleh kreditur atau karena perusahaan meningkatkan jumlah hutang 
hingga mencapai tingkatan yang lebih tinggi daripada yang diperkirakan kreditor. Hasil ini konsisten dengan penelitian yang dilakukan Wijaya dan Wibawa (2010) yang menyatakan bahwa secara parsial kebijakan hutang mempunyai pengaruh terhadap nilai perusahaan.

Investasi dengan menggunakan uji $\mathrm{t}$ mempunyai pengaruh terhadap nilai perusahaan, artinya Price Earnings Ratio yang tinggi menunjukkan investasi perusahaan yang baik dan prospek pertumbuhan perusahaan yang baik sehingga para investor akan tertarik. Semakin tinggi minat investor dalam berinvestasi pada perusahaan maka keputusan investasi tersebut berdampak pada meningkatnya nilai perusahaan. Dimana pengeluaran modal perusahan tampak sangat penting dalam upaya mengoptimalkan nilai perusahaan. Karena jenis investasi tersebut memberi sinyal positif tentang pertumbuhan pendapatan perusahaan yang diharapkan dimasa yang akan datang, sehingga dapat meningkatkan harga saham yang digunakan sebagai indikator nilai perusahaan. Dengan peluang investasi yang besar maka banyak calon investor yang akan berinvestasi sehingga nilai perusahaan dapat tercipta lebih maksimal. Hasil ini konsisten dengan penelitian yang dilakukan Rakhimsyah dan Gunawan (2011) yang menyatakan bahwa secara parsial kebijakan investasi mempunyai pengaruh terhadap nilai perusahaan.

Profitabilitas dengan menggunakan uji t mempunyai pengaruh terhadap nilai perusahaan, artinya semakin tinggi nilai profit yang didapat maka akan semakin tinggi nilai perusahaan. Karena profit yang tinggi akan memberikan indikasi prospek perusahaan yang baik sehingga dapat memicu investor untuk ikut meningkatkan permintaan saham. Permintaan saham yang meningkat akan menyebabkan nilai perusahaan yang meningkat dan profitabilitas yang tinggi akan memberikan sinyal positif bagi investor bahwa perusahaan menghasilkan dalam kondisi yang menguntungkan, hal ini menjadi daya tarik investor untuk memiliki saham perusahaan. Hasil ini konsisten dengan penelitian yang dilakukan Nurhayati (2013) yang menyatakan bahwa secara parsial profitabilitas mempunyai pengaruh terhadap nilai perusahaan.

Dividen, hutang, investasi, dan profitabilitas dengan menggunakan uji $\mathrm{F}$ secara simultan berpengaruh terhadap nilai perusahaan, besarnya pengaruh keempatnya adalah sebesar $87 \%$ variabel dari nilai perusahaan dapat dijelaskan oleh variabel DPR, DER, PER, dan ROE. Sedangkan sisanya sebesar 13\% dijelaskan oleh faktor-faktor lain diluar penelitian ini, yaitu rasio-rasio keuangan lainnya dan faktor-faktor selain rasio keuang.

\section{KESIMPULAN DAN SARAN}

\section{Kesimpulan}

Berdasarkan hasil analisis data mengenai pengaruh dividen, hutang, investasi, dan profitabilitas terhadap nilai perusahaan sektor aneka industri di Bursa Efek Indonesia 2012-2014, maka dapat diambil kesimpulan sebagai

berikut :

1. Dividen tidak berpengaruh terhadap nilai perusahaan sektor aneka industri di Bursa Efek Indonesia 2012-2014.

2. Hutang berpengaruh terhadap nilai perusahaan sektor aneka industri di Bursa Efek Indonesia 2012-2014.

3. Investasi berpengaruh terhadap nilai perusahaan sektor aneka industri di Bursa Efek Indonesia 2012-2014.

4. Profitabilitas berpengaruh terhadap nilai perusahaan sektor aneka industri di Bursa Efek Indonesia 2012-2014.

5. Dividen, hutang, investasi, dan profitabilitas berpengaruh secara simultan terhadap nilai perusahaan sektor aneka industri di Bursa Efek Indonesia 2012-2014. 


\section{Saran}

1. Bagi Peneliti Selanjutnya

a. Penelitian selanjutnya dapat memperbaiki keterbatasan yang ada dalam penelitian ini dan memperbanyak jumlah sampel serta tahun pengamatan untuk mendapatkan hasil yang menyeluruh.

b. Penelitian selanjutnya diharapkan dapat mengembangkan penelitian dengan faktor lain yang mempengaruhi nilai perusahaan diluar penelitian ini.

2. Bagi Investor

Diharapkan hasil penelitian ini dapat memberikan informasi mengenai faktorfaktor yang mempengaruhi nilai perusahaan yaitu dividen, hutang, investasi, dan profitabilitas.

\section{DAFTAR PUSTAKA}

Ahmad, dan Putri. 2012. "Pengaruh Dividen, Hutang, dan Profitabilitas Terhadap Nilai Perusahaan Manufaktur yang Terdaftar di BEI" Jurnal Riset Manajemen Sains Indonesia (JRMSI). Vol. 3, No. 1, 2012.

Arikunto, Suharsini. 2006. Prosedur Penelitian. Jakarta: Rineka Cipta.

Baridwan, Zaki. 2004. Intermediate Accounting. Yogyakarta: BPFE.

Basri. 2002. "Manajemen Keuangan" Edisi Ketiga. Yogyakarta : BPFE.

Brealey dan Myers. 2000. "Principles of Corporate Finance" Mc Graw Hill, New York.

$\begin{array}{ccr}\text { Brigham dan } & \text { Houston. } & 1998 . \\ \text { "Fundamental } & \text { of } & \text { Financial } \\ \text { Management" } & \text { Thomson, US of } \\ \text { America. } & & \end{array}$

Brigham, Eguene. F dan Joel F. Houston. 1999. Dasar-dasar Manajemen Keuangan. Jakarta: Salemba Empat.

Brigham, Eguene. F dan Joel F. Houston. 2003. Dasar-dasar Manajemen Keuangan. Jakarta: Salemba Empat.

Brigham, Eguene. F dan Joel F. Houston. 2004. Dasar-dasar Manajemen Keuangan. Jakarta: Salemba Empat.

Brigham, Eugene F dan Houston, Joel F. 2011. "Dasar-dasar Manajemen Keuangan buku 1" (Alih Bahasa : Ali Akbar Yulianto). Jakarta : Salemba Empat.

Brigham, Eugene F dan Houston, Joel F. 2011. "Dasar-dasar Manajemen Keuangan buku 2" (Alih Bahasa : Ali Akbar Yulianto). Jakarta : Salemba Empat.

Fama, E. F. dan K. R. French. 1998. "Taxes, Financing Decision, and Firm Value" The Journal of Finance LIII (Juni).

Ghozali, Imam. 2006. Pengembangan Analisis Multivariate dengan Program SPSS . Semarang: UNDIP.

Ghozali, Imam. 2009. "Ekonometrika Teori, Konsep, dan Aplikasi dengan SPSS 17" Semarang: Badan Penerbit Universitas Diponegoro.Hamid. 2012. Pengaruh Keputusan Investasi, Keputusan Pendanaan, Kebijakan Dividen, Struktur Kepemilikan Dan Ukuran Perusahaan Terhadap Nilai Perusahaan. Jurnal, 8 (2).

Hasnawati, Sri. 2005. "Dampak Set Peluang Investasi Terhadap Nilai Perusahaan Publik di Bursa Efek Jakarta" JAAI 9 (2).

Husnan, Suad. 1994. Dasar Dasar Teori Portfolio dan Analisis Sekuritas. 
Edisi 3. Yogyakarta : UPP AMP YKPN.

Jensen, M., dan W. Meckling. 1976. "Theory of The Firm: Managerial Behavior, Agency Cost, and Ownership Structure" Journal of Financial Economics 3.

Jensen, M.C., 1992. "Agency Cost of Free Cash flow, Corporate Finance and Take over" American Economics Review

Jogiyanto. 2010. Teori Portofolio dan Analisis Investasi. Yogyakarta: BPFE.

Mardiyanti, Umi. 2012. Pengaruh Dividen, Hutang dan Profitabilitas terhadap Nilai Perusahaan Manufaktur yang Terdaftar di Bursa Efek Indonesia (BEI) Periode 2005-2010. Jurnal Riset Manajemen Sains Indonesia (JRMSI), 3(1).

Modigliani, F., dan M. Miller. 1961. "Corporate income taxes and the cost of capital a correction" American Economic Review 53.

Nurhayati, Mafizatun. 2013. "Profitabilitas, Likuiditas, dan Ukuran Perusahaan Pengaruhnya Terhadap Kebijakan Dividen dan Nilai Perusahaan Sektor Non Jasa" Jurnal Keuangan dan Bisnis Vol. 5, No. 2.

Oladipupo, A.O dan Okafor, C.A. 2012. "Relative Contribution of Working Capital Management to Corporate Profitability and Dividend Payout Ratio : Evidence from Nigeria" International Journal of Business and Finance Management Research, 1.

Rakhimsyah dan Gunawan. 2011. "Pengaruh Keputusan Investasi, Keputusan Pendanaan, Kebijakan
Dividen, dan Tingkat Suku Bunga Terhadap Nilai Perusahaan" Jurnal Investasi Vol. 7, No.1, 2011.

Rakhimsyah, Leli Amnah dan Barbara Gunawan. 2011. "Pengaruh Keputusan Investasi, Keputusan Pendanaan, Kebijakan Dividen dan Tingkat Suku Bunga terhadap Nilai Perusahaan” Jurnal Investasi, 7 (1).

Sartono, R. Agus. 1997. "Manajemen Keuangan Teori dan Aplikasi" Edisi 4. Cetakan Pertama. Yogyakarta : BPFE.

Sartono, R. Agus. 2001. "Manajemen Keuangan: Teori dan Aplikasi” Edisi 4. Yogyakarta: BPFE.

Sekaran, Uma. 2000. Research Methods for Business. 3rd Edition, John Wiley and Sons Inc., New York.

Sofyaningsih, Sri dan Hardiningsih. (2011). Struktur Kepemilikan, Kebijakan Dividen, Kebijakan Hutang dan Nilai Perusahaan . Dinamika Keuangan dan Perbankan Vol. 3, No. 1 ISSN :1979- 4878.

Sugiyono. 2009. Metodologi Penelitian Bisnis. Cetakan ke-14. Bandung : Alfabeta.

Wahyudi, Untung dan Pawestri, Hartini. 2006. "Pengaruh Struktur Modal, Ukuran dan Kebijakan Dividen terhadap Nilai Perusahaan Manufaktur yang Go Public di Bursa Efek Indonesia" mSimposium Nasional Akuntansi 9 Padang.

Weston, Fred J., dan Brigham, Eugene F. 1991. Dasar-Dasar Manajemen Keuangan. Jakarta : Erlangga.

Weston, Fred J., dan Copeland, Thomas E. 1997. Manajemen Keuangan Jilid 2 
Edisi Kesembilan. Jakarta : Binarupa Aksara.

Wijaya dan Wibawa. 2010. "Pengaruh Keputusan Investasi, Keputusan Pendanaan, dan Kebijakan Dividen Terhadap Nilai Perusahaan" Simposium Nasional Akuntansi 13 Purwokerto. 